\title{
Evolutionary governance in mining: Boom and bust in peripheral communities in Sweden
}

Simon Haikola and Jonas Anshelm

The self-archived postprint version of this journal article is available at Linköping University Institutional Repository (DiVA):

http://urn.kb.se/resolve?urn=urn:nbn:se:liu:diva-159299

N.B.: When citing this work, cite the original publication.

Haikola, S., Anshelm, J., (2019), Evolutionary governance in mining: Boom and bust in peripheral communities in Sweden, Land use policy. https://doi.org/10.1016/j.landusepol.2019.104056

Original publication available at:

https://doi.org/10.1016/j.landusepol.2019.104056

Copyright: Elsevier

http://www.elsevier.com/

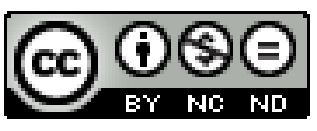




\section{Evolutionary governance in mining: Boom and bust in peripheral communities in Sweden}

\section{Introduction}

As the world market prices of iron ore soared in the $21^{\text {st }}$ century, the peripheral northern communities of Pajala and Kiruna in Sweden were subjected to enormous press from planning challenges. This paper analyses these challenges through the analytical framework of evolutionary governance (Van Assche et al., 2014), asking how decades of neoliberal reformation of the Swedish mining sector has affected the capacities of peripheral municipalities to manage boom and bust cycles.

The Swedish state has taken an interest in the mineral riches of the remote areas of the Arctic region for centuries, but only with the onset of industrialisation, and in particular the introduction of railway transportation, towards the turn of the previous century did large-scale, systematic extraction commence (Avango, 2005; Hansson, 1998; Sjöholm, 2010). Like its neighbours, Norway and Finland, Sweden built its $20^{\text {th }}$ century welfare state to a large extent on extraction of minerals and natural resources, creating peripheral communities heavily dependent on resource extraction. As the industrial base and welfare provision system of the country has changed, these communities have been left increasingly exposed and vulnerable to the vicissitudes of the global market, as was evidenced by the mineral boom and bust cycle between 2006 and 2018 (Haikola \& Anshelm, 2018; Rastad Bjørst, 2016; Similä \& Jokinen, 2018; Tarras-Wahlberg et al, 2017).

Like Norway and Finland, Sweden responded to the European Commission's raw materials initiative of 2008 (SEC, 2008) by formulating a national mineral strategy (Finnish Ministry of Employment and the Economy 2010; Norwegian Ministry of Trade and Industry, 2013; Swedish Ministry of Enterprise and Innovation, 2013) that explicitly aimed to facilitate the expansion of the domestic minerals sector. The EC's initiative emphasised the importance of self-sufficiency in regard to crucial raw materials. The role of Sweden in this context was obvious as it produces around $91 \%$ of the iron ore extracted within the EU and provides the majority of several other basic raw materials (Geological Survey of Sweden, 2015).

The Swedish mineral strategy, formulated by the liberal-conservative government and backed by broad parliamentary support, was premised on a neoliberal logic. It ascribed a role for the state as a facilitator for foreign and private investments into Sweden's untapped mineral resources, and emphasised it was imperative for peripheral communities to take every opportunity for economic development provided by private initiatives (Envall, 2015; Haikola \& Anshelm, 2016). Unlike Finland, which identified an active role for the state in its mining expansion (Liedholm Johnson \& Ericsson, 2015), and Norway, that is famed for its system for socializing profits from mineral extraction 
(Karlsson, 2017), Sweden foresaw an expansion led by private initiatives in which the state did little to regulate or actively distribute risks and profits according to a strategic vision. While the liberal-conservative government formulated the mineral strategy, it followed a logic of deregulation that had been adhered to since the early 1990s by right and left governments alike (Envall, 2015).

Just as regards school reformation (Edwards, 2018; Imsen et al, 2017) and financial deregulation (Nachemson-Ekwall $(2012,2014,2016)$, then, in mining policy Sweden has gone far beyond its traditional image of a social-democratic welfare state, to instead pursue a thoroughly neoliberal line. The present paper traces this development in the context of international developments, and then focuses on how the Swedish governance approach took on locally distinct forms in Kiruna and Pajala. As one is the home to state owned LKAB and the other hosted a much-publicised private mining venture that ended in bankruptcy, these cases offer an excellent opportunity to explore Swedish state governance of peripheral, resource dependent communities through boom and bust. The question we ask is: how are boom and busts in peripheral mining communities governed by the state and municipalities in Sweden today?

The analysis of the infrastructure changes in Pajala and Kiruna is based on press material from 2006 to 2018 with a focus on official statements by involved actors and signed opinion pieces written by involved actors or the local press. In addition, we analysed interviews with municipal politicians from Pajala (5) conducted in the spring of 2015 and from Kiruna (6) conducted in the summer 2016 (one interview was with the project leader for the city transformation) as well as minutes from parliamentary debates and reports from governmental agencies.

\section{Neoliberal mining governance in Sweden and developed countries}

In line with the theoretical perspective of evolutionary governance (Van Assche et al., this issue; Van Assche et al., 2014), we see governance as a continuous process, developing across scales where actors, institutions, and organisations interact along developmental paths that are constitutive but not wholly determinative of the way governance is effected in a given situation. Institutions, from this perspective, are 'the rules of the game' (Van Assche et al., 2014, p.21), the tools used to co-ordinate power, and the knowledge claims made by different actors and organisations. Although often codified and visible in the form of laws and regulations, institutions might also be informal, functioning as unwritten rules for governance in a given situation. From this observation, discourse can be seen as an inseparable aspect of governance because discourse sets the frames for knowledge about who is to be governed and how they are to be governed. Discourses develop in a co-constitutive relationship with actors and institutions. Actors perceive the world and the proper distribution of things through discourses, while discourses are changed through the knowledge claims and actions of the actors. That is, discourses are inscribed in and reinforced through institutions, and new or modified institutions may redraw discursive boundaries (Van Assche et al., 2014, p.42ff). 
Governance regimes are constituted by and evolve through different couplings between law, economy, and politics. The ways in which the law, economy, and politics are coupled encourage as well as prohibit certain steering mechanisms during planning (Van Assche et al., 2014). In the following, we will trace the development of Swedish mining governance since the 1960 through some key developments on different levels. First, we describe international processes of decentralisation, privatisation and neoliberalisation of planning and resource governance in developed countries. Then, we focus on how these processes have played out in Sweden, first in terms of national level financial and industrial governance, and then in terms of mining governance and planning. We conclude the background section by describing how these processes pressured the institutional capacity of Kiruna and Pajala during the mineral boom and bust of the 2000s. Throughout, we pay attention to the geographical effects of the governance processes we describe.

\section{Decentralisation and privatisation of resource governance in developed countries}

For several decades, governance paths in developed countries have shared two features with major implications for the management of natural resources: privatisation and decentralisation. Both are associated with the neoliberal redefinition of state responsibilities since the 1970s. Instead of acting as a crucial buffer against the destructive effects on society of market forces, the developed, post-Fordist state rather sees its task as facilitating the free play of the market (Crotty, 2012; Jessop, 2002a; King \& Le Gales, 2017; Peck, 1996; Wacquant, 2009). In this reformulation, shifting responsibilities to private and sub-state actors is a central aspect.

Privatisation means that private actors take on the provision of services and infrastructure developments previously regarded as key responsibilities of the state (Barnett, 2011; Lobao et al, 2018; Ochs, 2015; Reese \& Rosenfeld, 2002; Somerville, 2005; Stoker, 2004). In the case of resource governance, and mining in specific, this may have the effect both of allowing a larger share of private resource extraction, and of privatizing relations between company and local populations (Bridge, 2004, 2008; Castree, 2008a, 2008b; World Bank, 2011).

In the mining industry, this has meant an added focus on company responsibility for the socio-economic and environmental effects of extraction (e.g. Corrigan, 2018; Dashwood, 2012; Tarras-Wahlberg, et al, 2017). Agreements between mining companies and local communities thereby come to be seen as a more or less private matter, albeit regulated to some extent through legislation. In Canada, for example, private mining companies are now compelled by law to sign impact and benefit agreements with indigenous communities before extraction may begin, formally removing the central state from the equation (Campbell \& Prémont, 2017; Craik et al, 2017; Grant et al, 2014). Such developments have been criticised as a form of commodification of what should ultimately be a central state responsibility, and for burdening private companies with responsibilities for which they are not suited (Harvey, 2014; Stanley, 2016).

Through decentralisation, decision-making and responsibilities are transferred from the central state to governments on the regional and municipal level. In combination with 
tighter fiscal constraints and privatisation of services and infrastructure development, this redefines the role also of municipalities, who must function as actors on a market where they compete to attract external investments (Ochs, 2015; Reese \& Rosenfeld, 2002). While it is difficult to determine whether decentralisation has actually decreased state expenditure in total (Martinez-Vazquez \& Timofeev, 2009), it is evident that it has increased the geographic differences within developed countries (Brenner, 2009; LopezSantana, 2015). Decentralisation of government in combination with financial deregulation reinforces capital's tendency to accumulate in specific regions, and the geographically unequal patterns of neoliberal governance are often reinforced in and after economic downturns (e.g. Gray \& Barford; 2018; Kim \& Warner, 2018; Lobao \& Adua, 2011; Lobao et al; 2018).

In the context of mining governance, it is hard to find clear correlations between private/state share of resource extraction and socio-economic benefits in developed countries. Studies point to beneficial outcomes both from private set-ups and projects dominated by state actors (Borrini \& Jaireth, 2007; Brown et al, 2017; Phelan et al, 2017; Weber et al, 2013). In the specific case of relations between mining company and indigenous communities, there are claims that state retreat is a precondition for mutual benefits, given the colonial history of many developed mining nations (e.g. Alfred, 2009; Corntassel, 2012); others, however, argue that the results of privatisation of relations between indigenous communities and mining companies are uneven, at best (Larsen et al, 2018; Owen \& Kemp, 2012).

What is clear, however, is that state retreat in the guise of decentralisation may result in erosion of regulatory powers (e.g. Brockington et al, 2008; Cundill et al, 2013) and that local benefits may only accrue where local capacities are in place to absorb the potential windfall from extractive projects (Lockwood et al, 2010; Varghese et al, 2006). Peripheral communities with limited economic and institutional resources become severely pressured from the sudden spurts of industrial activity associated with extractive booms, as evidenced for example by studies in Australia (Carrington \& Pereira, 2011; Cheshire, 2010; Cheshire et al, 2014; Haslam McKenzie et al, 2009; Hossain et al, 2013; Petkova-Timmer et al, 2009; Phelan et al, 2017; Rolfe et al, 2007) and Canada (Parlee, 2015).

\section{Financial and industrial governance in Sweden in the neoliberal era}

In contrast to the traditional view of the Swedish state, for decades its approach to industrial policy and development has been premised on the neoliberal discourse of reluctance towards state involvement in the details of industrial governance. Most historians of economy agree that these redefinitions have occurred in response to the crisis of the Fordist industrial economy evident in Sweden as early as the 1960s (see Viktorov, 2007 for a literature overview). As observed by international scholars like Harvey (2005) and Jessop (2002a), the structural shift away from the Fordist accumulation regime has entailed a prioritisation of capital accumulation over social reproduction, giving rise to large geographical, socio-economic unevenness within nation states. Sweden has been no exception in this regard. 
One significant turn to the neoliberal evolutionary governance path was the deregulation of the Swedish financial market in the 1970s, inaugurating the 'era of finance capitalism' in the country (Nachemson-Ekwall, 2014, p.9). By deregulating capital flows and incorporating EU financial legislation, the Swedish state has gone further than many comparable countries in the dismantling of borders to foreign capital and foreign takeovers. According to Nachemson-Ekwall $(2012,2014,2016)$, this deregulation of the financial market has brought about a narrow focus on short-term value creation for shareholders, rather than the more long-term perspective on value creation associated with a broader stakeholder perspective. Thus, the financial markets have been de-coupled from strategic state visions about societal development. Similar de-couplings have been enacted in state-owned companies, where company charters and unclear operative structures have curtailed the state's strategic role (Dalborg, 2012; Laestadius, 2018).

Ease of access for foreign capital has important spatial effects. As protective barriers around domestic industries and financial regulations are removed, the tendency for capital, work and people to centralise is reinforced. Company head offices follow the capital and political power to urban economic centres, thereby eroding the tax base for peripheral communities. At the same time, foreign takeovers of Swedish companies often result in head offices moving abroad, in turn affecting the company's investment and recruitment strategies (Braunerhjelm \& Henrekson, 2012), while R\&D expenditure has become concentrated to a few large multinational companies (Andersson, 2012), whose effect on the Swedish economy is uncertain (Brogren, 2010). Further complicating the prospect for the Swedish countryside is the fact that natural resourcebased industries, which traditionally have been an important employer for peripheral communities, are vulnerable to rapid automatisation (SFS, 2014).

The Swedish economic crisis in the beginning of the 1990s also contributed to restructuring the country's economy by limiting both the ability and the willingness of the government to pursue a financial policy that could foster widespread economic growth. In part, this lack of an inclusive financial policy with respect to geography has been institutionally promoted through the government's commitment to a budgetary surplus irrespective of the economic burden placed on rural areas (e.g. Borg, 2004). At the same time, it has also become discursively restricted, as no political party seems to be prepared to risk appearing wasteful with taxpayer money. Hence, infrastructure investments have been insufficient for decades (Törnwall, 2018) and they have been unevenly distributed, as the peripheral regions in the north all receive infrastructure investments under the country average (Müller, 2017; WSP, 2017).

\section{The deregulation and decentralisation of mining governance and planning in Sweden}

Sweden has thus followed the main governance path taken by other developed nations. With respect to mining governance, neoliberalisation began in the 1990s when a number of legislative changes were made that lessened the state's control over the mining industry (Envall, 2015; Liedholm Johnsson, 2001, 2010). The state-owned mining company LKAB, the largest producer of iron ore in the European Union, has been 
targeted for possible privatisation on several occasions although so far it has maintained its state ownership, albeit through a charter that stipulates it is to be governed strictly as a business enterprise (Liedholm Johnson \& Ericsson, 2015). With the introduction of the Mineral Law in the beginning of the 1990s (see below), the state explicitly attempted to facilitate increased mining by easing regulatory burdens, and deregulation has continued through the adoption of one of the world's lowest taxes on minerals (e.g., Envall, 2015; Haikola \& Anshelm, 2016). The reformation of Swedish mining legislation was made in the context of financial deregulation sketched in the preceding section. The dominant logic determining the new Mineral Law and several subsequent amendments was thus that exploitation of Swedish minerals would be beneficial for everyone, regardless of where the capital came from (e.g. Government bill 1992/93: 238; SOU 2000:89).

Three main laws regulate Swedish mining: The Mineral Law, the Environmental Code, and the Planning and Building Act (PBA). The Mining Inspectorate, a subsidiary to the Geological Survey of Sweden, which holds an explicit mandate to stimulate an expansion of the Swedish mining industry, gives mining concessions under the Mineral Law. Importantly, the Mining Inspectorate is only mandated to validate the economic potential in the mineral asset, not the financial viability of the applicant company. With the Environmental Code entering into the permitting process only at a later stage, there has been critique against the Swedish system for favouring mining companies, and discontent among the indigenous Sami population towards what is perceived as insufficient state regulation of cumulative impacts from mining (Larsen et al, 2018). Indeed, mining concessions have been a largely foregone conclusions since the implementation of the law in the early 1990s, even though a number of high-profile environmental court cases in recent years indicate that the Mining Inspectorate will be more restrictive. These cases also indicate that the deregulatory approach to mining governance embarked upon by the Swedish state in the 1990s has resulted in an increasingly active and politicised judicial system (Anshelm et al., 2018). In the absence of an active state and powerful municipalities, planning processes tend to become politicised as issues between developers - often private - and environmental protection interests that use the leverage of the Environmental Code (Blücher, 2006).

While Sweden had a system of limited municipal self-government throughout most of the $20^{\text {th }}$ century, planning processes have become increasingly decentralised since the 1970s (e.g., Blücher, 2006). Adopted in 1987, the PBA was explicitly designed to increase locally anchored democracy in the planning process (Henecke, 2006). The PBA should be seen in the context of the systemic changes that were sketched above. If planning is viewed as the process of achieving political societal ideas and goals (e.g., Christoferson, 2000; Hermelin, 2005), then Swedish planning since the 1980s is premised on such goals being best achieved through market mechanisms. In this configuration, the state takes an indirect role, leaving investment decisions and issues of finance largely to be resolved through negotiations between municipalities, sub-state actors, and state actors, blurring the line between the public and the private sphere (Blücher \& Graninger, 2006; Tarras-Wahlberg et al, 2017; see also Hajer, 2003; Skelcher, 2000; Perry, 2003). Therefore, municipalities are seen as autonomous actors participating in a market of free competition rather than sub-state institutions representing the state. 
As Blücher (2006) argues, the PBA seems to have had a reverse effect to its aim of local empowerment. While it did indeed serve to lessen central state control of planning, it also failed to provide economically weak municipalities with leverage sufficient to take active control over planning processes. Instead of strategically steering planning, many municipalities have been forced to sell land to private developers in order to keep the municipal budget in check. While municipalities formally hold a key veto right to land use development in their control of the detailed development plan [Detaljplan], in reality, their bargaining position is often weak due to financial or other reasons (TarrasWahlberg et al, 2017). As we will argue in this paper, the planning monopoly cannot supply peripheral communities with the capacities required to both absorb the benefits and withstand the pressures associated with cyclical industries like mining.

The parliamentary decision in 1992 to end state subsidies to housing developments meant a final severing of the ties of central responsibility for local planning processes. Widely seen as the abdication by the state from housing politics (Blücher, 2006; Borg, 2004), it ties in with the larger pattern of developments, both internationally and in Sweden, that we have sketched in this background section. This pattern can be characterised as a centralisation of economic and political power and decentralisation of responsibilities. As a result of this style of governance, today's Swedish welfare state is unrecognisable from the one described by Esping-Andersen (1990) and Katzenstein (1985) just a few decades ago. For these researchers, the welfare state's primary role is to shield citizens from market forces. The Swedish government has adopted a role that is in many respects the reverse of this classic welfare state's, serving to abet market forces rather than protect vulnerable levels of society against their vagaries (e.g. Borg, 2004). These developments have left many Swedish municipalities strained and struggling to maintain services and crucial infrastructures (Blücher, 2006; SAERG, 2018).

The effects of neoliberal mining governance on peripheral communities - the governance paths of Pajala and Kiruna

The municipalities of Pajala and Kiruna are located in the sparsely populated county of Norrbotten, which comprises a quarter of Sweden's land area but has less than $3 \%$ of its population. The economic motor of the region has long been heavy, export-oriented industry, with iron ore producing, state-owned LKAB today being its largest employer, followed by steel-making SSAB (Sjöholm, 2016). Since the 1970s, the post-Fordist restructuring of the Swedish economy has further entrenched an already existing economic pattern of geographically uneven growth, with a large share of the Norrbotten population migrating to urban centres within the region or further south (Statistics Sweden, 2017).

Since the 1960s, the uneven distribution of resources has been identified and treated by the state as a political problem, and attempts at regional development have succeeded to some degree through the state subsidising the growth of urban regional centres in the north. For peripheral smaller communities, however, the existence of such centres has only further contributed to the outmigration of the working-age population. Through decades of more or less ambitious state policies - varying from pinpointed support for 
companies located or willing to re-locate to peripheral regions to inclusive and highly ambitious institutional frameworks for regional planning - the state has, however, failed to formulate a coherent strategy for regional development (Growth Analysis, 2012). Governmental policies launched under the rhetoric of geographically inclusive growth have not been able to answer the fundamental question of how growth can be achieved in municipalities with steadily shrinking work forces. The last decade has seen the disappearance of 10000 state sector jobs from the countryside (Gänger, 2015). With the municipal tax constituting $70 \%$ of the local administration's income, municipal politics for shrinking communities has become about struggling to sustain a decent level of welfare. For economically struggling communities, the only hope of large infrastructure projects resides in the possibility of attracting private developers that bring the financing with them (Blücher \& Graninger, 2006).

The development of both Kiruna and Pajala have been tightly linked to the industrial policy of the Swedish state. For the former, city development has followed the ups and downs of LKAB, which has operated there since the turn of the previous century and been wholly state-owned since 1976, but always intricately linked to the state (Liedholm Johnson, 2000). Crucial for the economic viability of large-scale mining in Kiruna was the extension of the railway from the port city of Luleå and the railway connection to the port in Narvik, Norway, at the beginning of the $20^{\text {th }}$ century (Hansson, 2015).

Being planned as a model mining town from the outset in early 1900, with the experience of severe social problems in the neighbouring mining town of Gällivare used as a cautionary example for the city planners, Kiruna has undergone several transformations necessitated by the operations of the mine (Brunnström, 1981; Hansson 1998; Sjöholm 2016). Previous boom and bust cycles have made lasting impacts on the town's development, as LKAB has been not only the prime employer but also a key service provider (Sjöholm, 2016). The heavy industry-driven boom of the postwar years saw explosive economic growth in the city, while the crisis of the 1970s led to a severe depression (Sjöholm, 2010). In the latter, LKAB came close to bankruptcy, and was saved by a state-directed program of severe rationalisations and production restructuring that laid the basis for the company as it exists today: a comparatively efficient producer of high-value iron products operated as a business rather than a stateowned enterprise (Hansson, 2015; Liedholm Johnson \& Ericsson, 2015).

The deep embeddedness of LKAB in Kiruna, where the fortunes of the company have determined the structure of Kiruna in a thoroughly physical sense, is problematic in that the municipality is completely reliant on a company into whose affairs it has limited insight (Tarras-Wahlberg, 2017). At the same time, it has made Kiruna relatively shielded from the economic effects of deindustrialisation, and it has managed to keep a relatively stable population since the crisis of the 1970s. Pajala's is a different story. As employment opportunities in the public sector and forestry have disappeared, this municipality located close to the Finnish border has seen a steady decline in its population, which has been more than halved since the 1950s (Poelzer \& Ejdemo, 2018; Statistics Sweden, 2017). Much of its working age population has moved to Kiruna to find work, returning after their working years, further stressing the municipality's elderly care budget. In 2015, the municipality had the country's second lowest percentage of working-age residents (WSP, 2017). In the 1970s, when LKAB 
investigated establishing a mine in Pajala, the municipality had hoped that a mining boom would eventually make the mineral-rich soil outside of town seem worth extracting, improving the town's economic prospects. Since then, this hope has lingered in the local mentality as a residual dream (Interview, May 22, 2015).

The events presented in the following sections should be understood in the context of huge price swings on the world market for iron ore in the $21^{\text {st }}$ century. After a dip in 2008 following the onset of the financial crisis, prices quickly bounced back due to demand from BRIC countries (Christian, 2009; Pettis, 2012). Optimism surged through the Swedish metals market and exploration costs remained high until 2012, when supply caught up with demand and prices started falling. In 2014, the spot price for iron ore was halved and the dramatic downturn continued into 2015, when iron ore prices had dropped 65\% from its 2013 price (Geological Survey of Sweden, 2015).

\section{The cases}

\section{Pajala}

In 2008, the company Northland Resources, formerly a Canadian exploration company that had acquired the rights to the Pajala iron deposits in 2005, announced a positive economic feasibility study and plans for three production lines. Having experienced decades of economic and demographic stagnation, the plans created local hope for a potential turnaround and a revival of the decades-old dream of an iron mine to compete with the one in Kiruna. The company planned to make the small municipality of Pajala Europe's second largest producer of iron, second only to its north-western neighbour, Kiruna (Bergman, 2012).

Despite this optimism, however, the plans also created a dilemma for the economically strained administration. A municipal budget, which was already insufficient to cover the demands of an aging population of around 6000, would now have to be adjusted to the prospect of a $50 \%$ population increase (Ejdemo \& Söderholm, 2008; Interview May 22, 2015). According to a subsequent report by the governmental coordinator for mining, the municipality had an investment budget of SEK 17 million and was facing investment requirements of around SEK 340 million. The administration was adamant that it would not allow a fly-in-fly-out situation, so it committed to creating the necessary infrastructure to house the expected influx of workers' families (Interviews May 22, 2015). Beginning in 2011, the municipal housing company, which had just recently liquidated housing due to excess supply, invested SEK 80 million in housing projects, partly financed through loans (ÅF Infraplan, 2014).

As the mine needed the municipality to improve its infrastructure, the local administration requested assistance from the central government. Before opening the mine and the downturn in mineral prices, many high profile governmental and 
oppositional party politicians visited the municipality, signalling state support for similar privately led local growth projects (Anderberg, 2013; Karlsson, 2013; Persson, 2012; Widmark, 2012). Despite this attention, the under-resourced municipal administration of Pajala believed that the government was not providing enough planning and financial assistance, and it was forced to rely to a significant extent on the County Administrative Board for planning support (Interviews May 22, 2015).

In the absence of a regulatory framework that clearly defined responsibilities for financing, the municipality was forced to implement several ad hoc solutions for the massive infrastructure project. Apart from the issue of housing, the most pressing matter was finding a solution for transport investment. The original plan to transport the iron ore to Finland was shelved when Northland Resources decided to use trucks to transport the ore 160 kilometres to Svappavaara, where the ore would be reloaded to trains that would transport it to the harbour in Narvik, Norway. While continuously, albeit unsuccessfully, lobbying the government to invest in a railroad connection between Pajala and Svappavaara, the municipality formed a purpose-specific road union together with Northland Resources and a number of business enterprises with a local and regional connection. This union would supply part of the investment for the road transport by securing loans from the Nordic Bank of Investment, and the government eventually agreed to redirect SEK 1 billion within the national infrastructure plan to investments in relation to the Pajala mine (Anderberg, 2013; Interview Sep 4, 2018; Lahti, 2012).

The environmental permit process went significantly smoother for Pajala and Northland Resources. By all accounts, the project fit perfectly into the role as a form of flagship project for the conservative-liberal government's Mineral Strategy and its planning largely coincided with governmental efforts to speed up the permit process for mining (Herin, 2011; Parliamentary debate 2009/10:9; Sundkvist \& Fagerlind, 2015a; Wrede, 2010). In a manoeuvre that has subsequently come to be heavily criticised, a little known state agency called the Finnish-Swedish Transboundary River Commission, with no expertise and no previous experience in mining issues, appropriated the environmental permit decision from the County Administrative Board and moved quickly to approve the first of the three mines. When the County Administrative Board, deprived of its usual mandate, attempted to insert its main environmental concerns into the municipal zoning plan, it was overruled by the Minister of Housing, Stefan Attefall (Sundkvist \& Fagerlind, 2015b).

As long as the project proceeded, the local administration had only praise for the way Northland Resources participated in the planning and financing of the project. Since the early days of project planning in 2006, the local administration had the impression from various company representatives that the company was seeking a long-term, serious, and constructive relationship with the municipality (Interview, May 22, 2015). In 2012, the city councillor Kurt Wennberg praised the spirit of the 'open' and 'fantastic' dialogue the company had continuously held with the residents of Pajala (Tjällman, 2012)

However, soon after the opening of the mine, Northland Resources announced a serious liquidity shortage, surprising investors as well Wennberg, who said: 'We, just like everybody else, were surprised when this news came so suddenly. People like us who are not privy to the discussions in the board room naturally feel that it could have been handled differently' (Karlsson, 2013). 
After a second restructuring at the end of 2013 proved insufficient and iron prices kept falling, Northland filed for bankruptcy in the fall of 2014. Just like the time leading up to the establishment of the mine, the post-bankruptcy years saw the municipality of Pajala, mainly through its city councillors and the county governor of Norrbotten, lobbying the government for state support, with their main hope lying in a state-led takeover of the mine by LKAB (Interviews, May 22, 2015; Jönsson 2014a, 2014b; Nordlund, 2014). However, no such help was offered as the Minister of Enterprise for the Social Democratic-Green government claimed it had done all it could in asking LKAB to consider all possibilities and that it was ultimately a company management decision (Engström, 2016; Johansson, 2015; Sundqvist \& Carr, 2016). Having seen a number of rescue attempts fail, the municipality was relieved to see, in August 2017, a group of billionaire financiers acquire the last remaining part of Northland's bankruptcy estate, averting the risk of the mine being dismantled and sold. In July 2018, the newly formed company, Kaunis Iron, officially restarted the mine, although with a much reduced workforce compared to the original plans of Northland Resources, and most employees were hired on short-term contracts (Isaksson, 2017; Nyberg, 2017a, 2017b). Bengt Niska, a former city councillor, described the feeling among Pajala's residents as being one of cautious optimism following the 'death-sentence' that was the bankruptcy (Sseruwagi, 2018).

\section{Kiruna}

In 2005, LKAB informed local Kiruna officials that a new main level of the mine would have to be opened at 1365 meters for mining operations to continue. This development led to discussions about infrastructure challenges and financing. Large parts of the city centre would have to be moved, including 1500 residents, to a new location. The main road, E10, would also need to be rerouted and a new railway station would need to be built. Complicating the issue further, the Geological Survey of Sweden, a state agency, had previously designated almost the whole area of Kiruna as a national interest for mineral extraction. If that designation were to be given priority in future municipal planning, the city would have to be moved tens of kilometres from its current location. The alternative, which was opted for, was to move the city a shorter distance and again several decades later when the mine would need to be expanded further (Eriksson, 2005). Residents, the Swedish Union of Tenants, and the Swedish Homeowners Association protested what they perceived as a forced removal that would not be duly compensated with equivalent housing (Bergmark, 2009; Ridderström, 2010).

By 2004, LKAB requested a new comprehensive plan that would facilitate the city transformation. In 2007, the municipality adopted a new plan that attempted to coordinate the mining interest with reindeer herding and recreational interests (Eriksson, 2005; Pettersson, 2010). Soon it became evident that no legislation was in place that could adequately guide the planning of an infrastructure challenge of this size and complexity. In 2007, the deficiency of legislative planning tools was highlighted by the National Board of Housing and Planning (NBHP) in a report arguing that LKAB and the municipality could not be expected to shoulder the financial burden for the move. In the report, the state agency argued that the state should act in its capacity as owner of 
the land through the National Property Board so as to take responsibility for the issue of property development. Furthermore, the NBHP recommended that the PBA be amended to guarantee that the relocation of houses was always secured before significant changes to the land could be approved and that the status of especially valuable cultural and natural environments be clarified (Bergmark, 2008a).

Since the report from NBHP, local politicians across the political spectrum, members of parliament with a regional connection, the local press, and the mining union in Kiruna have echoed its sentiments, arguing that the state should shoulder a larger share of the responsibility in its capacity as company owner. During the boom, when LKAB made record profits, voices were raised arguing that the state should abstain from withdrawing all of these profits and instead set them aside in a designated city transformation fund (Bergmark, 2008b; Linder, 2010; Nyström, 2008; Poromaa, 2009a). In the face of these claims, the conservative-liberal government reiterated up until the elections in 2014 that the issue must be conceived as one regulated sufficiently by the Mineral Law and therefore strictly a matter between the company of LKAB and the municipality. Few changes have been noticeable in this regard with the subsequent Social Democratic-Green government (Carr, 2016; Johansson, 2016; Nyström 2008; Wrede, 2016). This locally-based opinion has been especially aggrieved by the fact that the government has continued to claim a share of about SEK 3 billion even after mineral prices started falling and LKAB's record profits turned into losses (Abrahamsson, 2009; Bergmark, 2008b, 2010; Lindberg, 2009; Poromaa, 2009b, 2009a).

In addition to arguing for greater state responsibility, several municipal politicians have stressed the need for amendments to the regulatory framework to facilitate the planning of large infrastructure changes. The most complicated issue has been the compensation for residents forced to move into new apartments and houses. The municipality is prohibited by the Local Government Act to unduly benefit local inhabitants or companies, and it has therefore been hindered from giving away land or providing those forced to move with funds for new housing. City councillor Kristina Zakrisson has therefore argued for a change in the regulation regarding municipal subsidies (Junkka, 2011; Poromaa, 2011). The conservative opposition in the local administration has instead urged the government to require housing compensation from LKAB through changes to the company charter, arguing that the Mineral Law, the PBA, and the Law of Expropriation are applicable in individual cases but not for the purpose of moving entire towns (Sternlund, 2011a, 2011b; Svedell, 2011). Politicians from both sides of the political spectrum have agreed there is a need for a special 'Lex Malmfälten', ${ }^{1} \mathrm{a}$ 'Malmfälten law' (Abrahamsson, 2015; Björkenwall, 2012; Nyström, 2012; Sternlund, 2011a). Meanwhile, the Society for Nature Conservation and the Homeowners Association have criticised the government for allowing LKAB to compensate house owners at a level far below the cost of new housing. These organisations highlight a change in the Law of Expropriation made in 2010, whereby the requirement for expropriated housing to be compensated with the full cost of equivalent residence was removed. Accordingly, claimed the Society for Nature Conservation and the Homeowners Association, LKAB had been permitted to defer a significant part of its

\footnotetext{
${ }^{1}$ Malmfälten is a name for the mineral-rich area that encompasses both the cities of Kiruna and Gällivare in northern Sweden.
} 
costs to local residents, abetted by the government. (Lemker \& Karlsson, 2012; Stenberg, 2013). When the NBHP published its report 'Barriers and preconditions for housing construction in mining communities' (NBHP, 2013) in 2013, the government made clear how far it was prepared to go in meeting the local demands. It would consider offering credit guarantees to construction companies willing to invest in new residential housing, but there was no mention of subsidised housing construction. As would be expected, this did not go far in satisfying local criticism (Eliasson, 2013).

The local administration has expressed a sense of understanding towards the difficult position of the company having to deal with a task of this magnitude (Holma, 2011; Interviews May 31 \& June 2, 2016; Junkka, 2011; Poromaa, 2011; Sternlund, 2011a, 2011b; Svedell, 2011). Instead, the administration has focused its critique on what they perceive to be a state shirking its responsibilities (Interviews May 31 \& June 2, 2016). A steering group created to facilitate communication between the local administration and the central government has, by all accounts, been unsatisfactory (Interview June 2, 2016; SNAO, 2017). While the government has referred to the rule of municipal selfgovernment, the only possibility for the local administration to influence developments has been through its monopoly of infrastructure planning through the zoning plan, as regulated in the PBA. However, because the iron ore extraction was categorised as a national interest, the government could always overrule any local veto against continued mining operations, a fact that was also impressed on city councillor Zakrisson in a meeting with Maud Olofsson (Interview June 2, 2016). Furthermore, the National Audit Office concluded in its report on the city transformation (SNAO, 2017) that the decision to invest in a new ground level was made by the board on inadequate and difficult to assess calculations, further strengthening the impression that the municipality was facing a fait-accompli rather than a democratic decision. In its report, the Audit Office further found that even the government was informed about the plans only at an advanced stage.

Limited in its capacity to enforce its will, the municipal administration has considered itself lucky to have been able to negotiate significant parts of the financing when LKAB was making record profits. There is a widespread belief in the administration that the package for new municipal buildings agreed on in 2013 (SEK 3.74 billion) was a success for the municipal administration and would have been extremely difficult to achieve a year later when global iron prices plummeted (Interviews May 31 \& June 2, 2016).

\section{Discussion}

In the following discussion, we focus on the key governance aspects of steering mechanisms, forms of democracy, mobilised knowledge, and types of institutions (van Assche et al., 2014, p.72f.) to highlight and explain similarities and differences in the employment of land use planning tools during boom and bust in Kiruna and Pajala. After discussing how steering mechanisms, perceptions of democratic deficits, and specific forms of expert knowledge dominated planning procedures in both cases, we analyse 
the planning processes in terms of ad hoc governance driven by path dependencies in the institutional void created between formal and informal institutions (van Assche et al., 2014, p.21 ff.).

\section{Flexible steering, centre-periphery communication gap, and expert knowledge}

In our case studies, the Swedish state has employed highly flexible steering mechanisms. By deferring formal responsibilities to municipalities, agencies, and companies, the central state has deferred liabilities while managing to steer the municipalities to perform centrally-approved tasks (Foster et al., 2014; Jessop, 2002b, 2014; Levien, 2012; Somerville, 2005). The Pajala project fitted nicely into the political priorities of both the conservative incumbent government and the oppositional Social Democrats, appearing like the perfect example of how their policies of deregulation and investment facilitation would help foster local growth in ways that support an overall national export strategy. The speed at which the project was passed through the permit process and the unusual measure to bypass the County Administrative Board indicates that this was a project that received firm support from key state actors. From a narrow state perspective, it was largely a no-risk enterprise, as it cut its ties from the bankrupt mine and all subsequent rescue attempts. In Kiruna, the state similarly distanced itself from the operative procedures and liabilities by deferring all responsibility to the company, effectively using the company charter and the Mineral Law to shield it from responsibility. Due to the vagueness in responsibility distribution and information sharing in the management of state-owned companies in general (Dalborg, 2012) and LKAB in particular (SNAO, 2017), it is difficult to determine whether this is a result of active decisions or simply a lack of governmental interest.

In both planning processes, the large flexibility employed by the state was facilitated by a communicative gap between key actors and the state. Tarras-Wahlberg et al (2017) argue that municipalities tend to suffer an information deficit towards the mining company upon which they are reliant, and this is a problem that has been clearly visible both in Kiruna and Pajala. In the case of Kiruna, the Audit Office revealed significant communication deficiencies between the company management and state representatives on the board (SNAO, 2017). The lack of sites for decision-making (van Asshe et al., 2014, p.29) between the municipality and the company owner (i.e., the state) has contributed to an experience on the local level of flawed participatory democracy. Although the municipality was required to negotiate with the company, it lacked the institutional capacity to wield adequate influence. Furthermore, by distancing itself from the local proceedings, the state not only put pressure on the local administration but also on the company, which found itself in the position of having to involve itself directly in the city transformation (Tarras-Wahlberg et al, 2017; see Barnett, 2003, 2011; Cheshire et al., 2014; Cheshire, 2010 for more on how deregulation shifts responsibility from governments to the private sector).

For the administration in Pajala, the communication with the state remained open throughout the planning of the mine; however, as with the administration in Kiruna, both Pajala and the company were in a continuous struggle with the government for financial support. The establishment of the mine was democratically well anchored in 
the municipality. However, because both the state and local administration lacked insight into the vulnerabilities of Northland Resources, the latter was left vulnerable when the boom turned to bust. As in Kiruna and despite its flexible willingness for ad hoc support, the state defined the planning as fundamentally a matter of a privatemunicipal negotiation. As the state cut the communication channels following the bankruptcy, it also distanced itself from the wreckage, leaving the municipality and substate actors to manage the fallout from the bankruptcy.

The state's and the municipality's lack of insight into the vulnerabilities of Northland Resources also highlights the precarious position of a small municipality like Pajala being forced to rely on the privately-produced expert knowledge of a company willing to exploit its natural resources. In the absence of an institutionalised, mandatory investigation into the financial viability of an enterprise, there is neither the institutional capacity nor often the willingness to critically scrutinise the socio-economic plans of the entrepreneur, which were enthusiastically embraced by the Pajala administration. At the same time, the flexible steering mechanisms employed to bypass the standard planning institutions de-coupled a critical source of expert knowledge in the Regional Administrative Board's environmental department. In Kiruna, the absence of a critical discussion about the costs and benefits associated with the city move (see SNAO, 2017) is conspicuous, given the size of the investment. Given the absence of any real opposition, however, it is perhaps not surprising. In the following section, we turn to discuss such path dependencies.

\section{Path dependency in an institutional void}

The flexible and ad hoc steering mechanisms used in both the Pajala and the Kiruna planning process are deployed in the absence of formal institutions (van Asshe et al., 2014, p.21). As Larsson (1998) points out, the decentralisation of decision-making in Sweden has entailed a shift of responsibilities to municipalities, which are forced to orient themselves to market and non-state actors to attract investments and generate local growth. While this absence revealed itself through administrative and financial strains during the boom, it became significant only when mineral prices plummeted. The time after the boom has seen continued ad hoc management in both communities, and in the case of Pajala this management has been almost exclusively private, as seen in the private-led salvaging of the mine. Unsurprisingly, given the deeper institutional embeddedness of state-owned LKAB in Kiruna, the capacity to mitigate the bust was stronger here than in Pajala.

Indeed, the socio-economic embeddedness of LKAB in Kiruna seems to have created a path dependency in the early planning of the new ground level (e.g. Sjöholm, 2016). The results from the Audit Office report indicate that an expansion was treated as a foregone conclusion and never subjected to any rigorous analysis of costs and benefits. At the same time, the reliance of the municipal economy - not to mention culture and tradition - on LKAB created another form of path dependency (see van Assche et al., 2014, p.30). Although both the local administration and the company wanted to continue mining 
operations, this interdependency also raises doubts about the local administration's real possibilities to wield its one lever of legal power, the planning monopoly. The absence of adequate planning tools for an infrastructure project of this magnitude has been highlighted throughout by the municipal administration as well as sub-state agencies like the National Board of Housing and Planning, but the state has consistently posited the issue as being one sufficiently regulated by existing legislation. Thus, informal institutions could not compensate for the inadequacy of the existing formal institutions, even though some in the municipal administration perceived informal pressure from the government in some of the decisions made by sub-state actors in the planning process (Interview May 31, 2016). The lack of compensating informal institutions was probably exacerbated by the communicative gap between the conservative-liberal government in Stockholm and the Social Democrat administration in Kiruna up to 2014 (Interview June $2,2016)$.

In Pajala, the existence of informal institutions played a much more conspicuous role in the planning process. The support from actors in the central government during the permit process facilitated a speedy permitting process and the side-stepping of the Regional Administrative Board. Here, just as in Kiruna, the planning was driven by a strong path dependency, both in the form of a goal dependency (van Assche et al., 2014, p. 31) between key actors and in the community's residual dream of mining-led economic growth. These intertwined path dependencies pressured the planning time horizon, ultimately rushing the mine through the environmental permitting process (see van Assche et al., this issue).

At the same time, the esoteric aspect of such informal support revealed itself to be a problem when the boom turned to bust. As the state opted for liability minimisation instead of deep engagement, it became apparent that what seemed like a common goal was in fact only a common goal during the boom (Haikola \& Anshelm, 2018). The lack of formal support institutions stressed the municipal administration, which was forced to put its hope in the initiatives of private actors. Its hope that LKAB would take over the bankrupt mine, the reluctance of state actors to make such a demand on the company board, and the company's decision against a takeover also reveal a terrain where different logics, different visions, different discourses, and different formal and informal institutions collided.

Thus, the planning of the Pajala mine occurred on a discursive field of meaning-making where different, partly overlapping but to some extent competing, discourses determined the perceptions of the mine for key actor groups (Haikola \& Anshelm, 2018). In this context, the undetermined status of the Mineral Strategy appears significant, as it seems to have signalled a determination on the state level to pursue mining expansion that proved to be restricted to a rather passive role, something that left local actors aggrieved. Thus, the strategy took on a role of an 'open concept' (Van Assche et al., 2014, p.83) that served to unite actors for the purpose of planning, but also caused friction due to its fleeting status between being a formal and informal institution (Interview, May 20, 2015). After Northland Resources' bankruptcy, the municipal administration in Pajala quickly lost hope that the Mineral Strategy signalled a renewed state commitment to classical industrial policy. 
Maarten Hajer's notion of an 'institutional void' caused by the dispersal of power from the central state aptly captures the sense that both planning processes have left the municipal administration struggling in the face of insufficient planning regulations: 'There are no clear rules and norms according to which politics is to be conducted and policy measures are to be agreed upon' (Hajer, 2003, p.175). In this void, the infrastructure planning was achieved through what Sørensen and Torfing (2009) describe as 'pluricentric negotiations among relevant and affected actors interacting on the basis of interdependency, trust, and jointly developed rules, norms and discourses'; however, they also stress that such pluricentric configurations of governance are 'often unstable, diffuse and opaque' (p.236). Although a measure of flexibility in steering and the existence of informal institutions is welcomed and, in many cases, unavoidable, it is a concern that ad hoc steering plays such a large role in large infrastructure projects that have significant socio-environmental consequences. We argue that the explanation for the institutional void between local and central governments should be sought on the macro-scales of neoliberal governance, a claim that we examine in the conclusion.

\section{Conclusions}

The case studies reveal a form of governance that leaves peripheral municipalities with inadequate institutional capacity to manage large infrastructure challenges. They should be seen as qualitative evidence - which is needed to complement quantitative indicators (Lopez-Santana, 2015) - of the effects of neoliberal state restructuring and associated centralisation of capital and decentralisation of responsibilities. Although the municipalities are burdened with heavy liabilities, the state retains its key capacities. The lack of a regulatory planning framework has caused significant problems (see also SNAO, 2017), and applicable laws were inadequate for the purposes of aiding the planning of larger infrastructure projects, leaving the municipalities fending for themselves. The inadequacy of the formal institutions has generated ad hoc and flexible steering mechanisms that seem to function only during a boom, while placing severe pressure on the municipalities during a bust. ${ }^{2}$

The distant approach taken by consecutive governments to the transformation of Kiruna is perhaps the most conspicuous, given that it has been forced by the activities of a wholly state-owned company. It seems just as remarkable, however, despite differing circumstances of ownership, that a welfare state such as Sweden does not retain the institutional capacity to mitigate the effects of a mining bankruptcy for a vulnerable community like Pajala. The willingness to abet Northland Resource's enterprise during the boom and the reluctance to engage in the management of the abandoned mine during the bust could be seen as a form of reversed Keynesianism and the exact opposite of how a developed welfare state is meant to perform. In line with previous studies on

\footnotetext{
2 While the focus of the present paper is on infrastructural challenges, we would like to point the interested reader in the direction of existing literature on other effects associated with boom and bust cycles in small communities in developed countries, such as mental health, sexual health and violence (e.g. England \& Albrecht, 1984; Komarek \& Cseh, 2017; Freudenberg, 1984; Goldenberg et al., 2008; Goldenberg et al, 2010; Hayter \& Barnes, 2003; Hossain et al, 2013; James \& Smith, 2017).
} 
neoliberal governance, the 'institutional void' (Hajer, 2003, p.175) left by state restructuring is experienced especially in peripheral, economically weak communities (Gray \& Barford, 2018; Lobao \& Adua, 2011; Lobao et al, 2018).

The governance deficiencies revealed by the case studies are the result of a failure to embed an overall strategy for regional development into an institutional framework where municipalities retain the tools to exploit industrial opportunities and the state the capacity to soften the blows of the market in times of bust (see Van Assche et al., this issue; Van Assche et al., 2014). This failure should be understood in the context of decades of regional development policy where the problem formulation has shifted and the attempts to establish a long-term, coherent aim have failed (Growth Analysis, 2012). The reference to the wild west of Klondike made by a municipal politician in Pajala is strikingly apt: there is no evidence of any long-term strategy on behalf of either state or local administration beyond the mere hope for iron ore prices remaining high.

We argue that the passivity of the state in these developments should be seen in the context of its de-coupling from industrial policy, and the disembedding of the economy from political, strategic visions (Polanyi, 2001), which have reduced the steering mechanisms available for the state to anchor an industrial policy like the Mineral Strategy and to step beyond its now customary role as facilitator or ad hoc director. Further, our study indicates, in line with previous research, that the issue of state/private ownership is of less concern for local communities than the issue of local capacities to deal with potential risks and benefits associated with mineral booms and bust (Borrini \& Jaireth, 2007; Brown et al, 2017; Liedholm Johnson and Ericsson, 2015; Phelan et al, 2017; Weber et al, 2013).

To conclude, we argue the case studies in the present paper highlight the need for a profound rethinking on behalf of the Swedish state of its vision for regional development and its own role in directing industrial policy. In line with the argument put forward by the editors of the present issue (see Van Assche et al., this issue), we claim that the policies for regional development must be related to a long-term strategy. Thus, if the state wants to purse and facilitate the expansion of mining operations, it should also establish clear institutional capacities for mitigating the mine's environmental and social effects, in booms and especially during busts. 


\section{References}

Abrahamsson, 2009. 0. Abrahamsson. Slå vakt om LKAB. Norrländska Socialdemokraten, 2009-09-28.

Abrahamsson, 2015. O. Abrahamsson. Det behövs en Lex Malmfälten. Norrländska Socialdemokraten, 2015-02-17.

Alfred, 2009. T. Alfred. Colonialism and state dependency. Journal de la santé autochtone, 42-60.

Anderberg, 2013. J. Anderberg. Den bottenlösa gruvan. Fokus, 2013-02-08.

Andersson et al, 2012. M. Andersson, S. Dieden, O. Ejermo. Näringslivets forskningsverksamhet - hur sårbart är Sverige på en global marknad? Globaliseringsforum, Entreprenörskapsforum, Stockholm, 2012

Anshelm et al, 2018. J. Anshelm, S. Haikola, B. Wallsten. Politicizing environmental governance: A case study of heterogeneous alliances and juridical struggles around the Ojnare Forest, Sweden. Geoforum, 91, 206-215.

Avango, 2005. D. Avango. Sveagruvan: svensk gruvhantering mellan industri, diplomati och geovetenskap 1910-1934. PhD diss., Royal Institute of Technology, Stockholm.

Barnett, 2003. N. Barnett. Local government, New Labour and active welfare: A case of self-responsibilisation? Public policy and administration, 18 (3), 25-38.

Barnett, 2011. N. Barnett. Local government at the Nexus? Local government studies, 37 (3), 275-290.

Bergman, 2012. D. Bergman. An analysis of Northland Resources and the iron ore market. Unpublished master's thesis. Copenhagen Business School.

Bergmark, 2008a. K. Bergmark. LKAB vill ha första tjing. Norrbottens-kuriren, 200810-10

Bergmark, 2008b. K. Bergmark. S-krav: LKABs vinst ska betala omställningar. Norrbottens-kuriren, 2008-10-03.

Bergmark, 2009. K. Bergmark. Ingen revision av LKABs agerande. Norrbottenskuriren, 2009-04-14.

Björkenwall, 2012. R. Björkenwall. Staten måste ta mer ansvar. Norrländska Socialdemokraten, 2012-08-02. 
Blücher and Graninger, 2006. G, Blücher \& G, Graninger (Eds.) Planering med nya förutsättningar: Ny lagstiftning, nya värderingar. Stiftelsen Vadstena Forum för samhällsbyggande.

Blücher, 2006. G, Blücher. 1900-talet, det kommunala planmonopolets århundrade. G, Blücher, G, Graninger (Eds.) Planering med nya förutsättningar: Ny lagstiftning, nya värderingar. Stiftelsen Vadstena Forum för samhällsbyggande. Linköping University, Linköping. p. 133-157.

Borg, 2004. P. Borg. Systemskifte: En studie av tröghet vid fyra brytpunkter inom svensk välfärdspolitik. PhD diss., Stockholm University, Stockholm.

Borrini and Jaireth, 2007. G. Borrini, H. Jaireth. Sharing power: Learning-by-doing in co-management of natural resources throughout the world. International institute for environment and development, London.

Braunerhjelm and Henreksson 2013. P. Braunerhjelm, M. Henrekson. Entrepeneurship, institutions, and economic dynamism: Lessons from a comparison of the United States and Sweden. Industrial and corporate change, 22 (1), 107-130.

Brenner, 2009. N. Brenner. Open questions on state rescaling. Cambridge journal of regions, economy and society, 2, 123-139.

Bridge, 2004. G. Bridge. Mapping the bonanza: Geographies of mining investment in an era of neoliberal reform. Professional geographer, 56 (3), 406-421.

Bridge, 2008. G. Bridge. Global production networks and the extractive sector:

Governing resource-based development. Journal of economic geography, 8, 389-419.

Brockington, 2008. Nature unbound: Conservation, capitalism and the future of protected areas. Earthscan, London.

Brogren, 2010. C. Brogren: Den svenska paradoxen är ingen paradox. Entré, Iss.1, 2010.

Brown et al, 2017. J. Brown, T. Fitzgerald, J. Weber. Asset ownership, windfalls, and income: Evidence from oil and gas royalties. . Research working paper 16-12, Fed. Reserve Bank Kansas City.

Brunnström, 1981. L. Brunnström. Kiruna - ett samhällsbygge i sekelskiftets Sverige. Del 1, En bebyggelsehistorisk studie av anläggningsskedet fram till 1910. $\mathrm{PhD}$ diss., Umeå University.

Campbell and Prémont, 2017. B. Campbell, M.C. Prémont. What is behind the search for social acceptability of mining projects? Political economy and legal perspectives on Canadian mineral extraction. Mineral economics, 30 (3), 171-180.

Carr, 2016. D. Carr. Borgerlig regering skötte LKAB bättre. Norrländska

Socialdemokraten, 2016-01-14. 
Carrington and Pereira, 2011. K. Carrington, M. Pereira. Assessing the social impacts of the resources boom on rural communities. Rural sociology, 21 (1), 2-20.

Castree, 2008a. N. Castree. Neoliberalising nature: The logics of deregulation and reregulation. Environment and planning A, 40 (1), 131-152.

Castree, 2008b. N. Castree. Neoliberalising nature: Processes, effects and evaluations. Environment and planning A, 40 (1), 153-173.

Cheshire, 2010. L. Cheshire. A corporate responsibility? The constitution of fly-in, fly-out mining companies as governance partners in remote, mine-affected localities. Journal of rural studies, 26 (1), 12-20.

Cheshire et al, 2014. L. Cheshire, J.A. Everingham, G. Lawrence. Governing the impacts of mining and the impacts of mining governance: Challenges for rural and regional local governments in Australia. Journal of rural studies, 36, 330-339.

Christian, 2009. J. Christian. The Effects of the Financial Crisis on Metals Markets. Presentation for the World Bank, Extractive Industries Week, 2009-03-04.

Christoferson, 2000. I. Christoferson. Kommunal samhällsplanering. S. Berger, (Ed.) Det nya samhällets geografi. Uppsala Publishing House, Uppsala. p. 358-380.

Corntassel, 2012. J. Corntassel. Re-envisioning resurgence: Indigenous pathways to decolonization and sustainable self-determination. Decolonization: Indigeneity, education \& society, 1 (1), 86-101.

Corrigan, 2018. C. Corrigan. Corporate social responsibility and local context: The case of mining in Southern Africa. Resources policy, 55, 233-243.

Craik et al, 2017. Indigenous - corporate private governance and legitimacy: Lessons learned from impact and benefit agreements. Resources policy, 52, 379388.

Crotty, 2012. J. Crotty. The great austerity war: What caused the US deficit cricsis and who should pay to fix it. Cambridge journal of economics, 36. 79-104.

Cundill et al, 2013. Land claims and the pursuit of co-management on four protected areas in South Africa. G. Cundill, G. Thondhlana, L. Sisitka, S. Shackleton, M. Blore. Land use policy, 35, 171-178.

Dalborg, 2012. H. Dalborg. Ekonomiskt värde och samhällsnytta - förslag till en ny ägarförvaltning. SOU 2012:14, Stockholm.

Dashwood, 2012. H. Dashwood. The rise of global corporate social responsibility: Mining and the spread of global norms. Cambridge University Press, New York. 
Edwards, 2018. C. Edwards. What's behind the rising inequality in Sweden's schools, and can it be fixed? The local, 2018-08-22.

Ejdemo and Söderholm, 2008. T. Ejdemo, P. Söderholm. Local economic impact assessment of the Tapuli and Stora Sahavaara mining projects. Report on behalf of Raw Materials Group for Northland Resources Inc., September 2008. Raw Materials Group.

Eliasson, 2013. S. Eliasson. Riskerna bromsar. Norrländska Socialdemokraten, 201311-07.

England and Albrecht, 1984. J.J, England, S.L. Albrecht. Boomtowns and social disruption. Rural sociology, 49 (2), 230-246.

Engström, 2016. B. Engström. Näringsministern även till Pajala. Norrländska Socialdemokraten, 2016-02-01.

Envall, 2015. F. Envall. Storylines of progress and ambivalence: A discourse analysis of the Swedish parliamentary debate on mineral politics 1990-2015. Master's thesis, Linköping University.

Eriksson, 2005. L. Eriksson. Den stora flytten i Malmfälten är redan igång. Ny Teknik, 2005-06-07.

Esping-Andersen, 1990. G. Esping-Andersen. The three worlds of welfare capitalism. Princeton University press, New Jersey.

Finnish Ministry of Employment and the Economy 2010. Finland's Minerals Strategy. Kirjapaino Keili Ltd, Vantaa.

Foster et al, 2014. E. Foster, P. Kerr, C. Byrne. Rolling back to roll forward:

Depoliticisation and the extension of the government. Policy and politics, 42 (2), 225-241.

Freudenberg, 1984. W.R. Freudenberg. Boomtown's youth: The differential impacts of rapid community growth on adolescents and adults. American sociological review, 49, 697-705.

Geological Survey of Sweden, 2015. Statistics of the Swedish Mining Industry 2014. Periodiska Publikationer 2015:1, Stockholm.

Goldenberg et al, 2008. S. Goldenberg, J. Ostry, M. Koehoorn. Youth sexual behabiour in a 'Boomtown': Implications for the control of sexually transmitted infections. Sexually transmitted infections, 84, 220-223.

Goldenberg et al, 2010. S. Goldenberg, J.A. Shoveller, M. Koehoorn, A.S. Ostry. Consequences for young people of living and working in resource-extraction communities. Critical public health, 20 (2), 157-168. 
Government bill 1992/93: 238. Om ändringar i minerallagen m.m. Regeringens proposition 1992/93: 238.

Grant et al, 2014. A. Grant, D. Panagos, M. Hughes, M. Mitchell. A historical institutionalist understanding of participatory governance and aboriginal peoples: The case of policy change in Ontario's mining sector. Social science quarterly, 95 (4), 978-1000.

Gray and Barford, 2018. The depths of the cuts: The uneven geography of local government austerity. Cambridge journal of regions, economy and society, 11 (3), 541561.

Growth Analysis, 2012. The Swedish Agency for Growth Policy Analysis. Från aktiv lokaliseringspolitik till regional politik. Working paper 2012:18, Stockholm.

Gänger, 2015. H. Gänger. Så många jobb försvinner på landsbygden. Land, 2015-1101.

Haikola and Anshelm, 2016. S. Haikola, J. Anshelm. Mineral policy at a crossroads? Critical reflections on the challenges with expanding Sweden's mining sector. The extractive industries and society, 3, 508-516.

Haikola and Anshelm, 2018. S. Haikola, J. Anshelm. The making of mining expectations: Mining romanticism and historical memory in a neoliberal political landscape. Social and cultural geography, 19 (5), 576-605.

Hajer, 2003. M. Hajer. Policy without polity? Policy analysis and the insitutional void. Policy sciences, 36, 175-195.

Hansson, 1998. S. Hansson. Malm, räls elektricitet: Skapandet av ett teknologiskt megasystem i Norrbotten 1880-1920. P. Blomkvist, A. Kaijser. (Eds.) Den

konstruerade världen: Tekniska system i historiskt perspektiv. Bruno Östling, Symposion, Stockholm.

Hansson, 2015. S. Hansson. Malmens land: Gruvnäringen i Norrbotten under 400 år. Tornedalica, Luleå.

Harvey, 2014. B. Harvey. Social development will not deliver social license to operate for the extractive sector. The extractive industries and society, 1 (1), 7-11.

Harvey, 2005. D. Harvey. A brief history of neoliberalism. Oxford University Press, Oxford.

Haslam McKenzie et al, 2009. F. Haslam McKenzie, R. Phillips, S. Rowley, D. Brereton, C. Birdsall-Jones. Housing market dynamics in resource boom towns. Australian housing and urban research institute final report, no. 135, Australian Housing and Urban Research Institute, Perth. 
Hayter and Barnes, 2003. R. Hayter, T.J. Barnes. Resource town restructuring, youth and changing labour market expectations: The case of grade 12 students in Powell River, BC. BC Studies, 103, 75-103.

Henecke, 2006. B. Henecke. Plan och protest. En sociologisk studie av kontroverser, demokrati och makt i den fysiska planeringen. PhD diss., Lund University, Lund.

Herin, 2011. P. Herin. Sverige satsar. Veckans affärer, 2011-06-23.

Hermelin, 2005. B. Hermelin. Samhällsplaneringen och dess praktik i förändring. G. Forsberg, (Ed.) Planeringens utmaningar och tillämpningar. Uppsala Publishing House, Uppsala, p. 306-316.

Holma, 2011. S. Holma. Folket i Malmfälten måste få del av LKABs vinster. Norrländska Socialdemokraten, 2011-08-09.

Hossain et al, 2013. D. Hossain, D. Gorman, B. Chapelle, W. Mann, R. Saal, G. Penton. Impact of the mining industry on the mental health of landholders and rural communities in south-west Queensland. Australasian psychiatry, 21 (1), 32-37.

Imsen et al, 2017. G. Imsen, U. Blossing, L. Moos. Reshaping the Nordic education model in an era of efficiency. Changes in the comprehensive school project in Denmark, Norway, and Sweden since the millenium. Scandinavian journal of educational research, 61 (5), 568-583.

Isaksson, 2017. A. Isaksson. Avtal klart om Kaunisvaaragruvan. Norrbottens-kuriren, 2017-08-17.

James and Smith, 2017. There will be blood: Crime rates in shale-rich US counties. Journal of environmental economics and management, 84, 125-152.

Jessop, 2002a. B. Jessop. The future of the capitalist state. Polity Press, Cambridge, UK. Jessop, 2002b. B. Jessop. Liberalism, neoliberalism and urban governance: A statetheoretical perspective. Antipode, 34 (3), 458-78.

Jessop, 2014. B. Jessop. Repoliticising depoliticisation: Theoretical preliminaries on some responses to the American fiscal and Eurozone debt crises. Policy and politics, 42 (2), 207-223.

Johansson, 2015. N. Johansson. Mikael Damberg: Jag ställde krav på LKAB, det räckte inte. Norrländska Socialdemokraten, 2015-07-01.

Johansson, 2016. N. Johansson. Damberg tog kontakt med Jan Thelin.' Norrländska Socialdemokraten, 2016-01-14. 
Junkka, 2011. Å. Junkka. Flytten ingen höjdare. Norrländska Socialdemokraten, 201103-04.

Jönsson, 2014a. N. Jönsson. Mörk måndag i Pajala. Norrbottens-kuriren, 2014-07-09.

Jönsson, 2014b. N. Jönsson. Här vill ingen tänka på en möjlig konkurs. Norrbottenskuriren, 2014-10-28.

Karlsson, 2013. J. Karlsson. Löfven lurad i gruvan. Aftonbladet, 2013-01-29.

Karlsson, 2017. I. Karlsson. Norska landsbygden mår bättre än någonsin - utan olja. Extrakt, 2017-02-22.

Katzenstein, 1985. P. Katzenstein. Small states in world markets. Cornell University press, New York.

Kim and Warner, 2018. Y. Kim, M. Warner. Shrinking local autonomy: Corporate coalitions and the subnational state. Cambridge journal of regions, economy and society, 11 (3), 427-441.

King and Le Gales, 2017. D. King, P. Le Gales. The three constituencies of the state: Why the state has lost its unifying energy. The British journal of sociology, 68, 11-33.

Komarek and Cseh, 2017. T. Komarek, A. Cseh. Frcking and public health: Evidence from gonorrhea incidence in the Marcellus Shale region. Journal of public health policy, 38 (4), 464-481.

Laestadius, 2018. S. Laestadius. Klimatet och omställningen. Boréa, Umeå.

Lahti, 2012. G. Lahti. Sju byar slipper lastbilstransporter. Norrbottens-kuriren, 201201-20.

Larsen et al, 2018. R. Larsen, C. Österlin, L. Guia. Do voluntary corporate actions improve cumulative effects assessment? Mining companies' performance on Sami lands. Extractive industries and society, 5 (3), 375-383.

Larsson, 1998. L. Larsson. Nyheter i samspel. Studier i kommunjournalistik. PhD diss., Gothenburg University, Gothenburg.

Lemker and Karlsson, 2012. H. Lemker, M. Karlsson. En tillräckligt bra affär för staten. Norrbottens-kuriren, 2012-12-14.

Levien, 2012. M. Levien. The land question: Special economic zones and the political economy of dispossession in India. Journal of peasant studies, 39 (3-4), 933-969.

Liedholm Johnson, 2000. Om markägaren, upptäckaren och statens inflytande över mineraler i Sverige. Meddelande 4:81, Royal Institute of Technology, Stockholm. 
Liedholm Johnson, 2001. E. Liedholm Johnson, Rights to minerals in Sweden: Current situation from an historical perspective. Journal of energy and naturals resources law, 19 (3), 278-286.

Liedholm Johnson, 2010. E. Liedholm Johnson. Mineral rights: Legal systems governing exploration and exploitation. PhD diss., Royal Institute of Technology, Stockholm.

Liedholm Johnson and Ericsson, 2015. E. Liedholm Johnson, M. Ericsson. State ownership and control of minerals and mines in Sweden and Finland. Mineral economics, 28 (1), 23-36.

Lindberg, 2009. L. Lindberg. Häpnadsväckande om LKAB. Norrbottens-kuriren, 200908-18.

Linder, 2010. A. Linder. Vem ska stå för notan? Norrländska Socialdemokraten, 201004-28.

Lobao and Adua, 2011. L. Lobao, L. Adua. State rescaling and local governments' austerity policies across the USA, 2001-2008. Cambridge journal of regions, economy and society, 4, 419-435.

Lobao et al, 2018. L. Lobao, M. Gray, K. Cox, M. Kitson. The shrinking state?

Understanding the assault on the public sector. Cambridge journal of regions, economy and society, 11 (3), 389-408.

Lockwood et al, 2010. M. Lockwood, J. Davidson, A. Curtis, E. Stratford, R. Griffith. Governance principles for natural resource management. Society \& natural resources, 23 (10), 986-1001.

Lopez-Santana, 2015. M. Lopez-Santana. The new governance of welfare states in the United States and Europe. State University of New York Press, New York.

Martinez-Vazquez and Timofeev, 2009. J. Martinez-Vazquez, A. Timofeev. A fiscal perspective of state rescaling. Cambridge journal of regions, economy and society, 2, 85-105.

Müller, 2017. A. Müller. Stockholm, städerna och resten. Ord \& Visor förlag, Skellefteå.

Nachemson-Ekwall, 2012. S. Nachemson-Ekwall. An institutional analysis of crossborder hostile takeovers. Shareholder value, short-termism and regulatory arbitrage on the Swedish stock market during the sixth takeover wave. $\mathrm{PhD}$ diss., Stockholm School of Economics., Stockholm.

Nachemson-Ekwall, 2014. S. Nachemson-Ekwall. Fientliga bud. Teorierna, maktspelet, kortsiktigheten. SNS förlag, Stockholm. 
Nachemson-Ekwall, 2016. S. Nachemson-Ekwall. Hållbar ägararkitektur för Sverige. Global Utmaning, Sthlm Kommunikation \& IR, Stockholm.

NBHP, 2013. National Board of Housing and Planning. Barriers and preconditions for housing construction in mining communities. Stockholm.

Nordlund, 2014. S. Nordlund. Vägen från myren till diket. Norrbottens-kuriren, 201412-14.

Norwegian Ministry of Trade and Industry, 2013. Strategy for the mineral industry. Published by Ministry of Trade and Industry.

Nyberg, 2017a. M. Nyberg. Kommunchef blir gruvchef. Svt.se, 2017-08-17.

Nyberg, 2017b. M. Nyberg. Pajalagruvan säljs - avtal klart. Svt.se, 2017-08-17.

Nyström, 2008. U. Nyström. Oklart vem som betalar. Göteborgsposten, 2008-01-20.

Nyström, 2012. T. Nyström. Det behövs en Lex Malmfälten. Norrländska Socialdemokraten, 2012-02-17.

Ochs, 2015. H. Ochs. Privatizing the polity. State University of New York Press, New York

Owen and Kemp, 2012. J. Owen, D. Kemp. Social licence and mining: A critical perspective. Resources policy, 38, 29-35.

Parlee, 2015. B. Parlee. Avoiding the resource curse: Indigenous communities and Canada's oil sands. World development, 74, 425-436.

Parliamentary debate 2009/10:9. Swedish Parliament. Address 1, Maud Olofsson.

Peck, 1996. J. Peck. Work-place: The social regulation of labor markets. Guildeford Press, New York.

Perry, 2003. D. Perry. Making Space: Planning as a mode of thought. S. Campbell, S. Fainstein, (Eds.) Readings in planning theory. Second edition. Blackwell, Oxford, p. 142165.

Persson, 2012. I. Persson. Reinfeldt förstår inte gruvfebern. Aftonbladet, 2012-02-29.

Petkova-Timmer, 2009. V. Petkova-Timmer, S. Lockie, J. Rolfe, G. Ivanova. Mining developments and social impacts on communities: Bowen Basin case studies. Rural sociology, 19 (3), 211-228.

Pettersson, 2010. T. Pettersson. Kiruna får flytta när stålfarfar växer. Expressen, 2010-12-15. 
Pettis, 2012. M. Pettis. By 2015 hard commodity prices will have collapsed. China financial markets blog, Carnegie Endowment for International Peace, September 16. Business Insider. Retrieved from http://www.businessinsider.com/by-2015-hardcommodity-prices-will-have-collapsed-2012-9?IR=T

Phelan et al, 2017. A. Phelan, L. Dawes, R. Costanza, I. Kubiszewski. Evaluation of social externalities in regional communities affected by coal seam gas projects: $A$ case study from Southeast Queensland. Ecological economics, 131, 300-311.

Pierson, 2011. P. Pierson. The welfare state over the very long run. Arbeitspapier, No. 02/2011, Zentrum für Sozialpolitik, University of Bremen.

Poelzer and Ejdemo, 2018. G. Poelzer, T. Ejdemo. Too good to be true? The expectations and reality of mine development in Pajala, Sweden. Arctic review on law and politics, 9, 3-24.

Polanyi, 2001. K. Polanyi. The great transformation: The political and economic origins of our time. Beacon press, Boston.

Poromaa, 2009a. Å. Poromaa. Avsätt pengar till stadsflytten i Kiruna. Norrbottenskuriren, 2009-09-03.

Poromaa, 2009b. Å. Poromaa. Bygget av ny järnväg invigt. Norrbottens-kuriren, 200909-08.

Poromaa, 2011. Å. Poromaa. Zakrisson vill ha hjälp med stadsflytten. Norrbottenskuriren, 2011-02-22.

Rastad Bjørst, 2016. L. Rastad Bjørst, 2016. Saving or destroying the local community? Conflicting spatial storylines in the Greenlandic debate on uranium. The extractive industries and society, 3 (1), 34-40.

Reese and Rosenfeld, 2002. L. Reese, R. Rosenfeld. The civic culture of local economic development. Sage, Thousand Oaks.

Ridderström, 2010. M. Ridderström. Malmbergsborna kan avgöra kommunalvalet. Norrländska Socialdemokraten, 2010-09-14.

Rolfe et al, 2007. J. Rolfe, B. Miles, S. Lockie, G. Ivanova. Lessons from the social and economic impacts of the mining boom in the Bowen Basin 2004-2006. Australasian journal of regional studies, 13 (2), 134-153.

SAERG, 2018. Swedish Agency for Economic and Regional Growth. Politik för utvecklingskraft i hela Sverige - Utveckling, prioriteringar och resultat inom den regionala tillväxtpolitiken. Rapport 0257 . Stockholm 
SEC, 2008. Communication from the Commission to the European Parliament and the Council - The raw materials initiative: Meeting our critical needs for growth and jobs in Europe. Brussels 4.11.2008, COM(2008) 699 final.

SFS, 2014. Swedish Foundation for Strategic Research. Vartannat jobb automatiseras inom 20 år: Utmaningar för Sverige. Stockholm.

Similä and Jokinen, 2018. J. Similä, M. Jokinen. Governing conflicts between mining and tourism in the Arctic. Arctic review on law and politics, 9, 148-173.

Sjöholm, 2010. J. Sjöholm. Malmberget och Kiruna: Lika men olika. Norrbotten: Norrbottens läns hembygdsförenings tidskrift, Luleå: Norrbottens läns hembygdsförening, 102-115.

Sjöholm, 2016. J. Sjöholm. Heritagisation, re-heritagisation and de-heritagisation of built environments: The urban transformation of Kiruna, Sweden. PhD diss., Luleå University of Technology, Luleå.

Skelcher, 2000. C. Skelcher. Changing images of the state; overloaded, hollowed-out, congested. Public policy and administration, 15 (3), 3-19.

SNAO, 2017. Swedish National Audit Office. The relocation of Kiruna and Malmberget: The government and LKAB had inadequate decision-support data. RiR 2017:32, Stockholm.

Somerville, 2005. P. Somerville. Community governance and democracy. Policy and

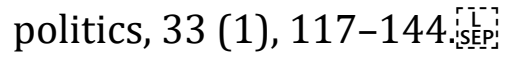

SOU 2000:89. Minerallagen, markägarna och miljön. Official Report of the Swedish Government.

Sseruwagi, 2018. J. Sseruwagi. Försiktigt hoppfullt när gruvan i Pajala nystartar: Konkursen var som en dödsom. Svt.se, 2018-04-17.

Stanley, 2016. A. Stanley. Resilient settler colonialism: “Responsible resource development", "Flow-through" financing, and the risk management of indigenous sovereignty in Canada. Environment and planning A, 48 (12), 2422-2442.

Statistics Sweden 2017. Statistiska Centralbyrån: www.scb.se

Stenberg, 2013. U. Stenberg. LKAB:s vinster viktigare än mänskliga rättigheter. Norrbottens-kuriren, 2013-02-21.

Sternlund, 2011a. H. Sternlund. Finansministern kontaktas om problemet. Norrländska Socialdemokraten, 2011-02-07. 
Sternlund, 2011b. H. Sternlund. M vill att LKAB ska ersätta bostäder. Norrländska Socialdemokraten, 2011-06-24.

Stoker, 2004. G. Stoker. Transforming Local Governance: From Thatcherism to New Labour. Basingstoke: Palgrave.

Sundkvist and Fagerlind, 2015a. F. Sundkvist, A. Fagerlind. Regeringen uppmanade till snabbare gruvtillstånd. Svenska Dagbladet, 2015-04-21.

Sundkvist and Fagerlind, 2015b. F. Sundkvist, A. Fagerlind. Northland och Pajala körde över minister. Svenska Dagbladet, 2015-03-30.

Sundqvist and Carr, 2016. K. Sundqvist, D. Carr. Ministerns löfte till Rantakyrö. Norrländska Socialdemokraten, 2016-02-02.

Svedell, 2011. H. Svedell. Därför har byggandet av nya bostäder dragit ut på tiden. Norrländska Socialdemokraten, 2011-09-16.

Swedish Ministry of Enterprise and Innovation 2013. Sveriges mineralstrategi: För ett hållbart nyttjande av Sveriges mineraltillgångar som skapar tillväxt i hela landet. Stockholm, Governmental print.

Sørensen, and Torfing, 2009. E. Sørensen, J. Torfing. Making governance networks effective and democratic through metagovernance. Public administration, 87 (2), 234-258.

Tarras-Wahlberg et al, 2017. H. Tarras-Wahlberg, F. Cronjé, F. Reyneke, S. Sweet. Meeting local community needs: The cases of iron ore mining in Sweden and South Africa. Extractive industries and society, 4 (3), 652-660.

Tjällman, 2012. J. Tjällman. Förändringens vindar I hjärtat av Tornedalen. Västerbottens-kuriren, 2012-07-07.

Törnwall, 2018. M. Törnwall. Infrastrukturen förfaller - Så många miljarder behövs. Svenska dagbladet, 2018-08-24.

Van Assche, et al, 2014. K. Van Assche, R. Beunen, M.Duineveld. Evolutionary governance theory: An introduction. Springer, New York.

Varghese et al, 2006. J. Varghese, N. Krogman, T. Beckley, S. Nadeau. Critical analysis of the relationship between local ownership and community resiliency. Rural sociology, 71, 505-527.

Viktorov, 2007. I. Viktorov. Fordismens kris och löntagarfonder i Sverige. PhD diss., Stockholm University. 
Wacquant, 2009. L. Wacquant. Punishing the poor: The neoliberal government of social insecurity. Duke University Press, Durham.

Weber et al, 2013. J. Weber, J. Brown, J. Pender. Rural wealth creation and emerging energy industries: Lease and royalty payments to farm households and businesses. Research working paper 1307, Fed. Reserve Bank Kansas City.

Widmark, 2012. J. Widmark. Northland Resources-paradprojekt med potential. Veckans affärer, 2012:21.

World bank, 2011. World bank/Raw materials group. Overview of state ownership in the global minerals industry. Long term trends and future. Extractive industries for development series, 20.

Wrede, 2010. M. Wrede. Järnet ska frälsa Pajala. Dagens samhälle, 2010-02-12.

Wrede, 2016. M. Wrede. Gruvtolvan mullrar mot regeringen. Dagens samhälle, 201601-21.

WSP, 2017. Regionernas kamp: Kunskapsstöd och dialogunderlag för svenska kommuner och regioner. WSP analys, Stockholm.

ÅF Infraplan, 2014. Samhällseffekter av fortsatt resp avvecklad gruvdrift i Kaunisvaara för Pajala med grannkommuner och det betydelsefulla norrbottniska gruvklustret. ÅF Infraplan, Report 2014-11-11. 